UDC 614.4: 616.9

DOI: $10.21668 /$ health.risk/2019.1.08.eng

Read

online

\title{
ASSESSMENT OF POTENTIAL EPIDEMIC HAZARDS CAUSED BY COMBINED FOCI WITH BACTERIAL, VIRAL, AND RICKETSIAL INFECTIONS
}

\author{
E.V. Kuklev ${ }^{1}$, A.A.Kovalevskaya ${ }^{2}$, B.L. Agapov², S.A Scherbakova ${ }^{1}$ \\ ${ }^{1}$ Rospotrebnadzor's Russian Scientific and Research Anti-Plague Institute "Microbe", 46 Universitetskaya Str., \\ Saratov, 410005, Russian Federation \\ ${ }^{2}$ Rospotrebnadzor's Anti-plague Station in Astrakhan', 3 Kubanskaya str., Astrakhan', 414057, Russian Federation
}

The authors performed epidemiologic analysis on 2,008 case histories of dangerous feral nidal infections among Astrakhan' region population over the last 17 years. It allowed them to characterize basic categories of epidemiologic risk related to such infections under contemporary conditions and determine the most significant statistically authentic $(p<0.05)$ criteria for assessing potential epidemic hazards caused by autonomous and combined natural foci with bacterial, viral, or ricketsial nature in the north and northwestern Caspian Lowlands. The determined criteria included a number of morbid cases among people, quantity of infection carriers and agents (fleas, ticks, and mosquitoes), contamination of rodents and infection carriers, circulating strains virulence, presence of camels, results of immunologic research performed on infection carriers and agents, immune layer among risk groups that include people and animals, ambient temperature, and average annual precipitations. The authors took epidemiological data obtained by Rospoterbnadzor's Astrakhan' Anti-plague Station, Astrakhan' Regional Center for Hygiene and Epidemiology, and A.M. Nichoga's Regional Infectious Clinical Hospital; the data were collected over 2000-2017 and were given in primary medical documentation including forms No. 027/U, No. 058/U, No. 060/U), as well as in reports with results of epizootologic examinations accomplished on the examined territories. The authors applied score assessment to work out an algorithm for determining qualitative and quantitative parameters of hazards caused for people by natural foci of plague, tularemia, leptospirosis, Crimean hemorrhagic fever, West Nile fever, and Astrakhan's ricketsial fever. This technique allows to perform scientifically substantiated epidemiologic zoning of territories with foci and to differentiate necessary prevention activities both in combined and autonomous infectious diseases foci with simultaneous reduction in expenditure.

Key words: potential epidemic hazards, natural foci with bacterial, viral, and ricketsial infections.

Introduction. There has been sporadic morbidity with tularemia, leptospirosis, brucellosis, Crimean hemorrhagic fever (CHF) [1, 17, 18], West Nile fever (WNF) [1-4, 21], and Astrakhan ricketsial fever (ARF) [6, 9] registered on the northern and northwestern Caspian Lowlands territories which were enzootic as per plague. In some years there was group morbidity or outbreaks of certain diseases (Crimean hemorrhagic fever in 2005-2008, West Nile fiver in 1999) [3, 10-12, 18-20]. Viral and ricketsial infections should be given special attention.

Thus, morbidity with CHF in Astrakhan region was registered every year (excluding 2014). There were three peaks detected in the overall morbidity dynamics; they occurred in 2001-2002,
2005-2007, and 2010, and all of them were followed by a drastic decrease in morbidity with the disease. But still, there is a statistically authentic $(\mathrm{P}<0.05)$ trend for morbidity with CHF to decline.

On the contrary, morbidity with WNF varied from 7.3 per 100,000 population in Astrakhan region in 2005 to 0.1 in 2007; in 2016 it amounted to $2.7 \pm 1.2$ on average. A calculated trend that describes dynamics in morbidity with this infection in Astrakhan region indicates there is a slight decrease in it. However, a model of the 6th order polynomial approximation proves there is likely to be an outbreak of the disease in the nearest future.

Astrakhan ricketsial fever is a new infectious disease [1]. People with the infection

(C) Kuklev E.V., Kovalevskaya A.A., Agapov B.L., Scherbakova S.A, 2019

Evgeniy V. Kuklev - Doctor of Medical Sciences, Leading researcher (e-mail:Kouklev50@mail.ru; tel. +7 (845) 273-46-48; ORCID iD: 0000-0002-9425-7194)

Anastasiya A. Kovalevskaya - an epidemiologist at the Epidemiological Department also responsible for providing biological safety (e-mail: anastasiya_scorpion1986@mail.ru; tel.: +7 (851) 233-37-00; ORCID iD: 0000-0002-8953-8813).

Boris L. Agapov - Deputy Director responsible for epidemiologic work, temporarily acting as Director (e-mail: antichum@, astranet.ru; tel.: +7 (851) 233-37-00; ORCID iD: 0000-0001-5395-6688).

Svetlana A. Scherbakova - Doctor of Biological Sciences, Deputy Director responsible for scientific and anti-epidemic work (e-mail: rusrapi@microbe.ru; tel.: +7 (845) 226-21-31; ORCID iD: 0000-0003-1143-4069). 
were first detected in 1978 in Krasnoyarskiy distirct of Astrakhan region, and in subsequent years it was also registered in other districts of the region. In 1978-1981 32 morbid events were registered; there were 47 in 1982, and 82 in 1988 [21]. Over the last decades morbidity with ARL has been registered in all the administrative districts in Astrakhan region, excluding Chernoyarskiy district. The highest morbidity levels are detected in Privolzhskiy and Narimanovskiy districts (783.6 and 523.6 per 100,000 population respectively).

Specific areas in natural foci are apparently different as per their potential epidemic hazards; given that, it is advisable, on one hand, to reduce volumes of epizootologic research as it is the most expensive component in the whole set of epidemiologic surveillance; on the other hand, one cannot degrade safety for population groups that run elevated risks of infection. All the above mentioned underlies a differentiated approach to epizootologic monitoring over foci with different epidemiologic status $[6,13,14]$.

As preventive (anti-epidemic) activities aimed at eliminating hazardous infections are at present accomplished as per specific nosologies on various administrative territories in the RF regions, it is necessary to work out complex prevention plans for feral nidal infections taking into account occurrence of combined foci and results of epidemiologic zoning performed as per epidemic risk levels.

Our research goal was to work out a procedure for assessing potential economic hazards caused by autonomous and combined foci of bacterial, viral, and ricketsial infections; the procedure should be relevant for Astrakhan region.

Data and methods. The authors applied data collected by Astrakhan Anti-Plague Station, Rospotrebnadzor's Regional Office in Astrakhan, Astrakhan Center for Hygiene and Epidemiology, as well as results of epizootologic and epidemiologic research performed in the region.

We performed epidemiologic analysis of data on epidemic and epizootic activities occurring in autonomous natural foci of plague, tularemia, leptospirosis, Crimean hemorrhagic fever, West Nile fever, and Astrakhan ricketsial fever, detected in Astrakhan region; the data were collected over 2000-2016. Overall, we examined 2,008 case histories.

We applied score assessment in a modification developed by E.V. Kuklev [7, 8]. All the data were statistically processed with conventional techniques [16].

Results and discussion. In order to perform epidemiologic zoning in Astrakhan region and differentiate existing autonomous and combined natural foci of hazardous viral, bacterial, and ricketsial infections into separate areas as per their potential epidemic risk levels, we analyzed epizootic and epidemiologic status in natural foci of the examined infections over 2000-2016. Basing on the results of epidemiologic analysis performed on 2,008 case histories related to Astrakhan region population morbidity with hazardous feral nidal infections (plague, tularemia, leptospirosis, Crimean hemorrhagic fever, West Nile fever, Astrakhan ricketsial fever) detected in 2000-2016, we determined the most significant parameters (features) that quantitatively and qualitatively reflect specific epidemiologic peculiarities of the examined infections (Tables 1 and 2).

Our choice of these parameters is substantiated taking into account a direct statistically authentic correlation $(\mathrm{P}<0.05)$ between each such parameter and people catching the infections. This proposition is also confirmed by the results obtained in previous research and potential epidemic hazards calculated for various infections: hemorrhagic fever with nephrotic syndrome $(r=+0.76)[5]$, plague, cholera, malaria $(r>+0.6)$, arbovirus infections (CHF virus circulation value $=0.79)[8,18]$, virus hepatitis of B and C type $(r>+0.7)$ [15], and assessment of potential hazards related to mass events $(100 \%$ coincidence of qualitative and quantitative parameters of potential epidemic hazards (PEH) related to mass events) [14].

Score assessment combined with conventional variation statistics techniques turned out to be the most relevant technique for assessing different parameters.

We detected an entire assembly of features for each parameter and spotted out three gradations, high, average, and low one, depending on assembly size and confidence intervals. Each 
Table 1

Parameters of potential epidemic hazards caused by combined natural foci with bacterial infections and their scores

\begin{tabular}{|c|c|c|}
\hline Parameters of potential epidemic hazards caused by natural foci & $\begin{array}{c}\text { Parameter } \\
\text { symbol }\end{array}$ & $\begin{array}{l}\text { Maximum } \\
\text { score }\end{array}$ \\
\hline \multicolumn{3}{|l|}{ PARAMETERS COMMON FOR ALL NATURAL FOCI } \\
\hline Physical square of an area within a natural foci & $\mathrm{S}$ & 2 \\
\hline Population density (urban and rural) & $\mathrm{P}$ & 3 \\
\hline PLAGUE & & 15 \\
\hline Number of disease cases among people & A & 7 \\
\hline $\begin{array}{l}\text { Number of plague carriers (average over long-term period/current): primary } \\
\text { ones, secondary ones, in settlements }\end{array}$ & B & 1 \\
\hline Contamination of rodents with plague agent & $\mathrm{D}$ & 2 \\
\hline Results of immunologic research on animals (on $\mathrm{Ag}$ and $\mathrm{Ab}$ ) & $\mathrm{M}$ & 1 \\
\hline $\begin{array}{l}\text { Number of plague carriers (Abundance index for hair, holes, microbiotopes) } \\
\text { (average over long-term period/current): in houses, in open biotopes }\end{array}$ & $\mathrm{C}$ & 1 \\
\hline Contamination of fleas with plague agent & $\mathrm{E}$ & 1 \\
\hline Virulence of plague agent strains & $\mathrm{V}$ & 1 \\
\hline Presence of camels (private sector and public livestock) & $\mathrm{L}$ & 1 \\
\hline TULAREMIA & & 15 \\
\hline Number of disease cases among people & A & 7 \\
\hline Immune layers among risk groups & $\mathrm{K}$ & 1 \\
\hline $\begin{array}{l}\text { Number of tularemia carriers (average over long-term period/current): in open } \\
\text { biotopes, in closed biotopes }\end{array}$ & B & 1 \\
\hline Results of immunologic research on animals (on $\mathrm{Ag}$ and $\mathrm{Ab}$ ) & $\mathrm{M}$ & 1 \\
\hline $\begin{array}{l}\text { Number of ticks (average over long-term period/current): in open biotopes, } \\
\text { number of registered species }\end{array}$ & $\mathrm{C}$ & 1 \\
\hline Contamination of ticks with tularemia agent & $\mathrm{E}$ & 2 \\
\hline Contamination of rodents with tularemia agent & $\mathrm{D}$ & 2 \\
\hline LEPTOSPIROSIS & & 15 \\
\hline Number of disease cases among people & A & 7 \\
\hline $\begin{array}{l}\text { Number of leptospirosis carriers (average over long-term period/current) in } \\
\text { anthropurgic foci: rats, cattle, pigs, dogs }\end{array}$ & B & 2 \\
\hline Contamination of carriers with leptospirosis agents: rats, cattle, pigs, dogs & $\mathrm{D}$ & 4 \\
\hline Results of immunologic research on animals (on $\mathrm{Ag}$ and $\mathrm{Ab}$ ): rats, cattle, pigs, dogs & M & 2 \\
\hline
\end{tabular}

Table 2

Parameters of potential epidemic hazards caused by combined natural foci with viral and ricketsial infections and their scores

\begin{tabular}{|c|c|c|}
\hline Parameters of potential epidemic hazards caused by natural foci & $\begin{array}{c}\text { Parameter } \\
\text { symbol }\end{array}$ & $\begin{array}{l}\text { Maximum } \\
\text { score }\end{array}$ \\
\hline \multicolumn{3}{|c|}{ PARAMETERS COMMON FOR ALL NATURAL FOCI } \\
\hline Physical square of an area within a natural foci & $\mathrm{S}$ & 2 \\
\hline Population density (urban and rural) & $\mathrm{P}$ & 3 \\
\hline CRIMEAN HEMORRHAGIC FEVER & & 15 \\
\hline Number of disease cases among people & A & 7 \\
\hline $\begin{array}{l}\text { Natural and climatic conditions on a specific area: average temperature (Janu- } \\
\text { ary, July), } \\
\text { Average annual precipitation }\end{array}$ & $\begin{array}{l}\mathrm{T} \\
\mathrm{U}\end{array}$ & 2 \\
\hline Number of primary CHF virus carriers: D. marginatum ticks & $\mathrm{C}$ & 2 \\
\hline
\end{tabular}




\begin{tabular}{|c|c|c|}
\hline $\begin{array}{l}\text { Detection of CHF virus markers: ticks, small mammals, blood serum of farm } \\
\text { animals, human blood serum }\end{array}$ & M & 4 \\
\hline WEST NILE FEVER & & 15 \\
\hline Number of disease cases among people & $\mathrm{A}$ & 7 \\
\hline Sum of average daily temperature is higher than $+10^{\circ} \mathrm{C}$ & $\mathrm{T}$ & 2 \\
\hline $\begin{array}{l}\text { Number of primary WNF virus carriers (mosquitoes of Culex species): in open } \\
\text { biotopes, in closed biotopes }\end{array}$ & $\mathrm{D}$ & 3 \\
\hline $\begin{array}{l}\text { Detection of WNF virus markers: mosquitoes, ticks, wild waterfowl, farm wa- } \\
\text { terfowl, human blood serum }\end{array}$ & M & 3 \\
\hline ASTRAKHAN RICKETSIAL FEVER & & 15 \\
\hline Number of disease cases among people & A & 7 \\
\hline $\begin{array}{l}\text { Number of primary rickettsia ticks carriers: in open biotopes, in settlements } \\
\text { on cats and dogs }\end{array}$ & $\mathrm{C}$ & 4 \\
\hline Detection of ARF virus markers: ticks, human blood serum & M & 4 \\
\hline
\end{tabular}

gradation corresponded to a quantitative score given to each parameter; 14-20 scores corresponded to high gradation, 7-13, average one, and less than 7 scores meant gradation was low. This distribution of scores is a sum of scores given to criteria common for all feral nidal infections (5 scores) and a sum of scores which are specific for this or that infection (15 scores maximum).

For example, potential epidemic hazard caused by a natural plague focus is calculated as follows:

$$
\begin{aligned}
& \Pi \ni \mathrm{O}_{1}=S+P+A+B+C+D+E+M+L+V= \\
& =2+1+0+0,5+0,5+0+1+0+1+0,5=6,5,
\end{aligned}
$$

where ПЭО1 is a parameter that describes potential epidemic hazard existing in a natural plague focus, $S$ is a physical square of an area within a natural focus, $\mathrm{P}$ is population density (urban and rural), $\mathrm{A}$ is a number of disease cases among people, $\mathrm{B}$ is a number of plague carriers, $\mathrm{C}$ is a number of plague agents, $\mathrm{D}$ is contamination of rodents, $\mathrm{E}$ is contamination of fleas, $\mathrm{M}$ is a results obtained in immunologic research, $\mathrm{L}$ is presence of camels, $\mathrm{V}$ is virulence of strains (for white mice or guinea pigs).

Calculated potential epidemic hazard of an area within a natural plague focus amounts to 6.5 scores and it means the hazard is low.

Parameters of potential epidemic hazards existing on territories of combined natural foci were calculated as a sum of values obtained for potential epidemic hazards as per each separate infection divided by a number of these infections:

$$
\begin{gathered}
\mathrm{PEH}=\left(\mathrm{PEH}_{1}+\mathrm{PEH}_{2}+\mathrm{PEH}_{3}+\right. \\
\left.+\mathrm{PEH}_{4}+\mathrm{PEH}_{5}+\mathrm{PEH}_{6}\right): 6,
\end{gathered}
$$

where $\mathrm{PEH}$ is a potential epidemic hazard existing in a combined natural focus, $\mathrm{PEH}_{1}$ is a potential epidemic hazard of a natural plague focus; $\mathrm{PEH}_{2}$, tularemia; $\mathrm{PEH}_{3}$, leptospirosis; $\mathrm{PEH}_{4}$, Crimean hemorrhagic fever; $\mathrm{PEH}_{5}$, West Nile fever; $\mathrm{PEH}_{6}$, Astrakhan ricketsial fever.

Conclusion. We proposed the most statistically significant criteria for assessing potential epidemic hazards existing in autonomous and combined natural foci of bacterial, viral, and ricketsial infections (plague, tularemia, leptospirosis, Crimean hemorrhagic fever, West Nile fever, and Astrakhan ricketsial fever) in northwestern Caspian Lowlands. We have developed an algorithm based on score assessment for qualitative and quantitative estimation of potential epidemic hazards caused by such natural foci. If the proposed procedure is implemented, it will allow to perform scientifically substantiated epidemiologic zoning of a natural focus territory and to differentiate prevention activities thus reducing expenditure. It is recommended to apply this approach when accomplishing epidemiologic surveillance over feral nidal infections in northwestern Caspian Lowlands.

Funding. The research was not granted any sponsor support.

Conflict of interests. The authors state there is no any conflict of interests. 


\section{References}

1. Androsova S.V., Rogatkin A.K. Izuchenie ekologii arbovirusov i rasprostranenie prirodno-ochagovykh boleznei na territorii Astrakhanskoi oblasti. [Studies of the ecology of arboviruses and dissemination of natural-focal infections in the territory of the Astrakhan region]. Astrakhan', 1996, 32 p. (in Russian).

2. Butenko A.M., Kovtunov A.I., Dzharkenov A.F., Zlobina L.V., Grishanova A.P., Azaryan A.R., Larichev V.F., Shishkina E.O. [et al.]. Epidemiologicheskaya kharakteristika likhoradki Zapadnogo Nila $\mathrm{v}$ Astrakhanskoi oblasti [Epidemiological characteristics of West Nile fever in the Astrakhan Region]. Voprosy virusologii, 2001, no. 3, pp. 34-35 (in Russian).

3. Zhukov A.N., Filippov A.G., Krasnova E.N. Epidemiya likhoradki Zapadnogo Nila v Volgogradskoi oblasti [West Nile fever epidemic in the Volgograd region]. Zdorov'e naseleniya i sreda obitaniya, 2000, vol. 92, no. 11, pp. 9-10 (in Russian).

4. Zhukova L.I., Rafeenko G.K., Gorodin V.N., Vanyukov A.A. Kliniko-epidemiologicheskaya kharakteristika likhoradki Zapadnogo Nila v Krasnodarskom krae [Clinical-epidemiological characteristics of West Nile fever in the Krasnodar Territory] Zhurnal mikrobiologii, epidemiologii i immunobiologii, 2016, no. 2, pp. 74-80 (in Russian).

5. Kresova Yu. A., Garanina S.B., Kazakova L.V., Kuklev E.V., Safronov V.A. Sochetannye ochagi aktual'nykh dlya Saratovskoi oblasti prirodno-ochagovykh infektsionnykh boleznei [Combined foci of relevant for the Saratov Region natural-focal infectious diseases]. Zdorov'e naseleniya i sreda obitaniya, 2014, vol. 255, no. 6, pp. 30-32 (in Russian).

6. Kolobukhina L.V., L'vov S.D. Arbovirusy serogruppy kaliforniiskogo entsefalita v Rossii i ikh znachenie $\mathrm{v}$ infektsionnoi patologii [Arboviruses of California encephalitis serogroup in Russia and their role in infectious pathology]. Vestnik Rossiiskoi Akademii meditsinskikh nauk, 2011, no. 5, pp. 41-45 (in Russian).

7. Kuklev E.V., Kokushkin A.M., Kutyrev V.V. Kolichestvennaya otsenka velichiny epidemicheskogo potentsiala prirodnykh ochagov chumy i optimizatsiya epidemiologicheskogo nadzora za etoi infektsiei [Quantitative assessment of epidemic potential value of natural plague foci and optimization of epidemiological surveillance over the infection]. Epidemiologiya $i$ infektsionnye bolezni, 2001, no. 5, pp. 10-13 (in Russian).

8. Kuklev E.V., Kovalevskaya A.A., Kovtunov A.I. Kriterii otsenki potentsial'noi epidemicheskoi opasnosti sochetannykh prirodnykh ochagov bakterial'nykh i virusnykh infektsii [Criteria for the assessment of potential epidemic hazard of combined natural foci of bacterial and viral infections]. Materialy XIII Mezhgosudarstvennoi nauchno-prakticheskoi konferentsii, 2016, Saratov, pp. 136-137 (in Russian).

9. L'vov D.K., Klimenko S.M., Gaidamovich S.Ya. Arbovirusy i arbovirusnye infektsii [Arboviruses and arboviral infections]. Moscow, 1989, 335 p. (in Russian).

10. L'vov D.K., Pisarev V.B., Petrov V.A., Grigor'eva N.V. Likhoradka Zapadnogo Nila: po materialam vspyshek v Volgogradskoi oblasti v 1999-2002 gg. [West Nile fever: a case study of theoutbreaks in the Volgograd Region in 1999-2002]. Volgograd, 2004, 102 p. (in Russian).

11. Maleev V.V., Galimzanov Kh.M., Butenko A.M., Cherenov I.V. Krymskaya gemorragicheskaya likhoradka [Crimean Congo hemorrhagic fever]. Moscow, Astrakhan' Publ., 2003, 118 p. (in Russian).

12. Onishchenko G.G., Efremenko V.I., Beier A.P. Krymskaya gemorragicheskaya likhoradka [Crimean Congo hemorrhagic fever]. Moscow, Vserossiiskii uchebno-nauchno-metodicheskii tsentr po nepreryvnomu meditsinskomu i farmatsevticheskomu obrazovaniyu Publ., 2005, 269 p. (in Russian).

13. Onishchenko G.G., Kutyrev V.V., Krivulya S.D. [et al.]. Strategiya bor'by s infektsionnymi boleznyami i sanitarnaya okhrana territorii v sovremennykh usloviyakh [Strategy to counter infectious diseases and sanitary protection of the territory under current conditions]. Problemy osobo opasnykh infektsii, Saratov, 2006, vol. 2, no. 92, 2010, pp. 5-9 (in Russian).

14. Onishchenko G.G. Patyashina M.A., Udovichenko S.K. [et al.]. Kolichestvennaya otsenka potentsial'noi epidemicheskoi opasnosti massovykh meropriyatii s mezhdunarodnym uchastiem ee aprobatsiya v usloviyakh Universiady-2013 [Quantitative Assessment of Potential Epidemic Hazard of Mass Events with International Participation and Methodology Approbation in the Context of Universiade2013]. Problemy osobo opasnykh infektsii, Saratov, 2015, pp. 5-9 (in Russian).

15. Pichugina L.M., Kologorov A.I., Danilov A.N., Kozhanova O.I. Epidemiologicheskie osobennosti ostrogo gepatita $\mathrm{v}$ Saratovskoi oblasti v sovremennykh usloviyakh [Epidemiological peculiarities of severe hepatitis in the Saratov Region under current conditions]. Problemy osobo opasnykh infektsii, Saratov, 2010, vol. 3, no. 105, pp. 25-27 (in Russian). 
16. Plokhinskii N.A. Biometriya [Biometrics]. Moscow, 1970, 336 p. (in Russian).

17. Smirnova S.E., Sedova A.G., Zimina Yu.V., Karavanov A.S. O sluchayakh Krymskoi-Kongo gemorragicheskoi likhoradki v Astrakhanskoi oblasti [Concerning the cases of Crimean Congo hemorrhagic fever in the Astrakhan Region]. Voprosy virusologii, 1990, no. 3, pp. 228-231 (in Russian).

18. Smirnova S.E. Smirnova S.E. Krymskaya-Kongo gemorragicheskaya likhoradka (etiologiya, epidemiologiya, laboratornaya diagnostika) [Crimean Congo hemorrhagic fever (etiology, epidemiology, laboratory diagnostics)]. Moscow, Akademiya truda i sotsial'nykh otnoshenii Publ., 2007, 302 p. (in Russian).

19. Tarasevich I.V. Astrakhanskaya pyatnistaya likhoradka. Moscow, Meditsina Publ., 2002, 171 p. (in Russian).

20. Ugleva S.V., Burkin A.V., Shabalina S.V. Sovremennaya epidemiologo-entomologicheskaya otsenka transmissivnykh likhoradok, dominiruyushchikh na territorii Astrakhanskoi oblasti [Current epidemiological-entomological assessment of transmissible fevers dominant in the territory of the Astrakhan Region]. Epidemiologiya i vaktsinoprofilaktika, 2011, no. 4, pp. 5-11.

21. Gratz N.G. Emerging and resurging vector-borne diseases. Annual Review Entomology, 1999, vol. 44, pp. 51-75.

22. Lvov D.K., Butenko A.M., Gromashevsky V.L., Kovtunov A.I., Prilipov A.G., Kinney R., Aristova V.A., Dzharkenov A.F. [et al.]. West Nile and other zoonotic viruses as examples of emergingreemerging situations in Russia. Archives of virology. Supplementum, 2004, 18, pp. 85-96.

Kuklev E.V., Kovalevskaya A.A., Agapov B.L., Scherbakova S.A. Assessment of potential epidemic hazards caused by combined foci with bacterial, viral, and ricketsial infections. Health Risk Analysis, 2019, no. 1, pp. 78-83. DOI: 10.21668/health.risk/2019.1.08.eng

Received: 01.11.2018

Accepted: 26.01 .2019

Published: 30.03.2019 